railroad right of way cut the mill almost in two and it was torn down. The last time the writers visited the scene the old stone burrs and a few wooden cogwheels were lying in the grass by the railway fence, mute evidence of an industry that once was essential to the lives of people in that vicinity.

A few rods south of the old mill site an open green in the timber shows where a burial place has been. A couple of marble slabs lay in the grass and a few scattered pieces are trodden upon by livestock as they graze in summer. On one stone we read the inscription, "Robert Arbuthnot, died May 8, 1856, aged 46 years." Early settlers, but apparently nothing known of their history. 'There are other Arbuthnots known now residing in other states, and we are told that Asbury Arbuthnot is now a rich ranchman of the United States of Columbia in South America, but none clairn interest in these forgotten graves.

Britt, Iowa, May 6, 1926.

\title{
SIGNIFICATION IN 1854 OF IOWA AND O'THER INDIAN NAMES
}

Mr. LeClaire of Davenport, so long the Indian interpreter of the government, at a late interview gave the following interpretation of several Indian names:

"Iowa"-means literally, "Here is the place." Driven, as were the Iowas and Sacs from Wisconsin and Illinois beyond the Mississippi, they exclaimed, "Here is the place" for us to live unmolested; and so it measurably proved for many years. This etymology differs somewhat from the signification given by Senator Dodge, which is "None such," as well as from that of Washington Irving, or some romantic writer, who represents an Indian on a high Illinois bluff, overlooking Iowa, "Iowa, beautiful, beautiful." The idea conveyed by Mr. LeClaire is that of a place of retreat, or a happy refuge from enemies.

"Keokuk"-means the "Watchful fox," Keokuk being a Fox Indian, or "He that goes everywhere.' So that it will be well to keep a sharp lookout for the Foxes down at the "Gate City of 
Iowa"; since, if they follow their Indian namesake, they will go cverywhere and need watching to be caught.

In pronunciation, the best usage puts the accent on "I" in the word "Iowa," and gives the final "a" the sound as in Africa, Asia, and the like-not I-o-way, but I-o-wah, more nearly. The Indians had no accent, in the proper sense, but a stress on each syllable alike. So in "Keokuk," the accent is on the syllable "Ke." It is hardly needful for old residents to be told this; but abroad these names are often strangely spoken.

"Des Moines,' Mr. LeClaire says, is a corruption of "Moins," in French, meaning "The Less" as applied to the river, and not as it is commonly understood, "le riviere," Des Moines-river of monks, but "le riviere Des Moins" (if the French is allowable,) "the less river." So that, in reality the spelling of the name should be if compounded into one word, "Demoins," which, by dropping the " $\mathrm{s}$ " in pronunciation would be as near the French and Indian, as the English tongue can well be brought. Thus much is said of names of places; which, if not soon fixed by those who [know] their significance, will soon pass away, and be known only in the romance of the past.-Iozoa City Journal. Reprinted in The Democratic Union, Keosauqua, Iowa, July 29, 1854. (In the Newspaper Division of the Historical, Memorial and Art Department of Iowa.)

\section{FROM THE PLAINS}

During the past week several men have returned from the Plains; some from as far out as Fort Laramie. They report grass plenty, and the emigrants are generally getting along well. Some few cases of cholera, small pox, and measles, and a few deaths. They bring no news particularly interesting.-The Frontier Guardian, Kanesville (Council Bluffs), Iowa, June 12, 1850. (In the Newspaper Division of the Historical, Memorial and Art Department of Iowa.) 
Copyright of Annals of Iowa is the property of State of Iowa, by \& through the State Historical Society of Iowa and its content may not be copied or emailed to multiple sites or posted to a listserv without the copyright holder's express written permission. However, users may print, download, or email articles for individual use. 